\title{
The Key Role of Togo Government in Corporate Social Responsibility (CSR), and Corporate Governance (CG) Among Togo Companies
}

\author{
Bienmali Kombate ${ }^{1}$, Xu Wanxiao ${ }^{2}$ \\ ${ }^{1}$ Faculty of Economic and Business, University of Lome, Lomé, Togo \\ ${ }^{2}$ College of Public Administration, Huazhong University of Science and Technology (HUST), Wuhan, People's Republic of China
}

Email address:

bienmalikombate@student.uns.ac.id (B. Kombate), bienmali41@gmail.com (B. Kombate), xuwanxiao@sina.com (Xu Wanxiao), 656978045@qq.com (Xu Wanxiao)

\section{To cite this article:}

Bienmali Kombate, Xu Wanxiao. The Key Role of Togo Government in Corporate Social Responsibility (CSR), and Corporate Governance (CG) Among Togo Companies. European Business \& Management. Vol. 3, No. 5, 2017, pp. 76-81. doi: 10.11648/j.ebm.20170305.11

Received: July 26, 2017; Accepted: October 11, 2017; Published: November 15, 2017

\begin{abstract}
Beyond to bring light on the role played by Togo government in business in ethical way to contribute to business and it community welfare, in this paper, we highlight the key role that played the government as a driver of Corporate Social Responsibility (CSR) and regulator of Corporate Governance (CG). The paper was drawn based on recent and previous studies. Lee, M. (2008). (Vogel, 2005: 2); Hasan Al-Zu'bi (2014). Garriga and Melé (2004), (Donaldson \& Preston, 1995; Freeman, 1994), Friedman's criticism (1970), Laura A., Josep M., Antonio T., Atle M., and Francesco P. (2008). We focus by a basic analysis basing on at several mejor that government interfere in business and we deducted for good ethical way in CSR and CG need government intervention. The concluding discussion assesses implications of and further research questions arising from the findings concerning the impact that challenge manager in managerial decision by government interference in CSR and CG.
\end{abstract}

Keywords: CSR, CG, Government, Togo

\section{Background}

Corporate social responsibility (CSR) is a management concept that refers to the activities through which companies commit to integrate social and environmental concerns in their business operations and manage their stakeholders such as employees, customers, suppliers, shareholders, etc. The concept of CSR indicates the sense of responsibility of a company towards the economic, social and ecological environment in which it operates. Companies are so-called "socially responsible" when they take responsibility for their impact on society. The World Business Council for Development (World Business Council for Sustainable Development (WBCSD)) defines CSR as: "The commitment of companies to adopt ethical behavior and contribute to economic development while improving the quality of life of employees, their families and the local community and society as a whole. "Lee, M. (2008). CSR and it governance become nowadays, One of the widely debated topic in corporate motivation. The question at this level is what incentives firms might have to implement CSR actions, defined above, as practices that improve the workplace and benefit society in ways that go above and beyond what companies are legally required to do (Vogel, 2005: 2). Previous studies showed that companies always have a strength formalization of ethical rules which foster relationships with shareholders and provides and maintain investor confidence. (R. Ramakrishnan 2007) every organization, as they grow has many stakeholders like shareholders, employees, customers, suppliers, community, etc. For survival and growth, they have to rely upon healthy relations with all these stockholders; (Robert Allen Peterson, O. C. Ferrell - 2005). Whose in their studies, sets the agenda for business ethics and corporate responsibility in the future. It brings together ideas, challenges, and proposed solutions for thinking about and implementing effective ethics programs in business schools and business organizations. Management guru peter drucker (1992) keenly observes trust is an essential commodity at all level of business operations and 
relationships. Shareholders must trust manager, employers must trust employees, buyers must trust sellers, and government must trust business. And this trust must be mutual and reciprocal. Trust among this and the many others is the results of an ethical good practice. In ethical views, all business has to give privilege to social responsibility, protecting his environment regardless of it government policy. Togo, a West African country with its giant industries, its free zone and those ports which feeds the Sahel countries of Africa makes it's the business center in the West African sub region. Business ethics or organizational ethics aiming the social responsibility of the company and its governance through behavior and organizational development is one of the forms of applied ethics in business in Togo to a specific field which examines. In this paper, we will focus on the ethical behavior key role played by government in corporate social responsibilities (CSR), corporate governance (CG) synergies and interrelationships among locals, national, multinational and international enterprises which operate in Togo.

\section{Business Ethics, Corporate Social Responsibility (CSR), and Corporate Governance (CG) Among Togo Companies}

The study of proper business policies and practices regarding potentially controversial issues, such as corporate governance, insider trading, bribery, discrimination, corporate social responsibility and fiduciary responsibilities, business ethics is the set of norms, moral rules that govern how businesses operate, how business decisions are made and how people are treated Business ethics is the application of general common principles to business and encompasses a broader range of issues and concerns than laws do. Ethics as defined norms and moral behaviors practices in professional field, everything that is legal is not ethical. Ethics involves learning what is right or wrong, and then doing the right thing but "the right thing" is not nearly as straightforward. Business ethics are often guided by law, while other times provide a basic framework that businesses may choose to follow in order to gain public acceptance; Hasan Al-Zu'bi (2014) Business ethics is the behavior that a business adheres to in its daily dealings with the world. The ethics of a particular business can be diverse. They apply not only to how the business interacts with the world at large, but also to their one-on-one dealings with a single customer. Jorge (2014); Ahmad M. Zamil (2014); has also rely that business ethics is the behavior that a business adheres to in its daily dealings with the world. It is a moral principle that guide the way a business behaves. In such of these moral principles, much business ethics (also corporate ethics) is a form of applied ethics or professional ethics that examines ethical principles and moral or ethical problems that arise in a business environment. It applies to all aspects of business conduct and is relevant to the conduct of individuals and entire organizations. Business ethics are often guided by law, while other times provide a basic framework that businesses may choose to follow in order to gain public acceptance. Business ethics are implemented in order to ensure that a certain required level of trust exists between consumers and various forms of market participants with businesses. Among countries such as Togo, where business dealing in good ethical ways, certain ethical rules falls within the law by a government body regulation.

In Togo, the Chamber of Commerce and Industry of Togo (CCIT) which set professional association leaders from each functional area part of business as regulators in business ethics issues who are often attempt to provide a standard of conduct to guide business practice. All business in Togo which had dealing has benefit business ethics which aiming in the following purposes:

1. Providing to business practitioners the tools for dealing with moral complexity in business

2. Leading business decisions in an ethical component

3. Ethical implications must be weighed before acting.

\subsection{Corporate Governance (CG) Practice Among Companies Which Are Dealing in Togo}

Corporate governance is the system of rules, practices and processes by which companies in their mission are directed and controlled to achieve their vision. Corporate governance essentially involves balancing the interests of company stakeholders such as shareholders, management, customers, suppliers, financiers, government and the community. Since corporate governance also aiming and providing the framework for obtaining a company's goals, it encompasses practically all function area of management, from action plans and internal controls to performance measurement and corporate disclosure. Corporate governance often defined as policies, procedures, and rules that determine how a corporation is managed, as defined by the company's bylaws, corporate charter, policies, and applicable laws. Following the flurry of record-setting corporate bankruptcies in 2001 and 2002, corporate governance became a high-profile topic in ethical debate. To avoid the worst, government intervenes with laws in some concrete cases by encouraging compliance of some ethical norms for the interest of the stakeholders and the public and also aiming to provide a perfect ethical deal in business among companies which are dealing in that country for the purpose as followed:

1. To avoid bankruptcy,

2. financial or accounting fraud

3. unfair competition

4. To enable stakeholders and public confidence in companies and markets

5. To attract foreign investors to invest in his country with a good ethical climate.

Togo is one among Countries which strive to have a business ethical practice between companies with a high level of corporate governance.nowadays, it is not enough for a company to merely be profitable; it also needs to demonstrate good corporate citizenship through environmental awareness, ethical behavior and sound 
corporate governance practices. Most companies corporate Governance represents the moral framework, the ethical framework, and the value framework under which company leaders often takes decisions. In the long to run an ethical behavior as a positive impact on the company's performance, many institutions and research gap has show how investor can analyze company corporate governance as followed:

1. Standard and Poor's GAMMA score (GAMMA stands for governance, accountability, management, metrics and analysis) evaluates the governance of companies in emerging markets, according to shareholder influence, shareholder rights, transparency and board effectiveness.

2. Institutional Shareholder Services (ISS) has an executive compensation database, and its Governance Risk Indicators measure companies' governance performance on audit, board, compensation/remuneration and shareholder rights issues.

3. The Investor Responsibility Research Center Institute funds corporate governance research, and makes it widely available to the public. For example, it published a report in July 2010 called "Compensation Peer Groups at Companies with High Pay" that examined a number of S\&P 500 companies whose executive compensation was out of line with the executives' performance, and the compensation provided by similar companies.

4. Governance Metrics International (GMI) develops risk ratings and research related to companies' environmental, social, governance and accounting practices. It examines all the companies in the MCSI world index, the DJ STOXX 600 and the S\&P 1500, and updates its data monthly

5. Glass, Lewis \& Co. helps investors evaluate the risk of investing in a company as it pertains to governance, business, legal, political and accounting issues. It also provides proxy research and voting recommendations.

Corporate Governance deals with the questions:

1. Who benefits from corporate decisions/senior management actions?

2. Who should benefit from corporate decisions/senior management actions?

"Corporate governance is about promoting corporate fairness, transparency and accountability" J. Wolfensohn, president of the Word bank, as quoted by an article in Financial Times, June 21, 1999. Key elements of good corporate governance norms are: honesty, trust and integrity, openness, performance orientation, responsibility and accountability, mutual respect, and commitment to the organization.

Good Corporate Governance is key of Profits Growing and Reputation. It represents the relationship among stakeholders that is used to determine and to control organizational strategic direction and it performance. Business ethics is acting like democracy and is a lot easier in theory more than in practice. 'Does a Business ethic pay? Ethics and profits do mix well. The UK's Institute of Business Ethics (IBE) finds that in a sample of FTSE 350 firms 'ethical' companies outperformed those which made no such claims on three out of four financial measures (market value added [MVA], economic value added [EVA] and price/earnings ratio). In the long run the old age "Honest is the best policy", may be the best strategy to adopt. Corporate governance to contribute to the company profit growth, avoid harm for stakeholder and benefit the belief of the public should be applied as followed:

1. Best treatment of accounting and management practices;

2. Compliance of law in true letter and spirit;

3. Adherence to ethical standards for effective management and distribution of wealth

4. Discharge of social responsibility for sustainable development of all stakeholders

Corporate governance as mentioned above is the long term strategic emphasis objectives and plans which are established for the proper use of management structure in place. Companies that provide good governance, both in terms of practices and results can expect the backing not only of investors but of customers too.

The foundation for ethical behavior goes well beyond corporate governance and it policies of any given company in any country, but it also depends greatly on corporate social responsibility as a duty of company vis-a-vis of its environment.

\subsection{Corporate Social Responsibility (CSR) Practice Between Togo Companies}

Over the past 20 years, corporate social responsibility (CSR) has become a central issue in corporate debate and it represents the driver behind many social science publications. One widely debated topic is corporate motivation. The question at this level is what incentives firms might have to implement CSR actions. AS mentioned above in this paper like practices that improve the workplace and benefit society in ways that go above and beyond what companies are legally required to do' (Vogel, 2005: 2). Several theories had tried to explain this topic. Garriga and Melé (2004), for instance, have identified four main families of explanations; each of them can be broken down into several theories. The first two are called the political and ethical approaches. They converge to the extent that both of them justify CSR on the basis of motives transcending business life, considering that it is companies' duty to take in account social responsibility practices because they belong to a community that is greater than them-selves. The third approach, revolving around and named an Integrative theory which emphasizes the idea those social demands can be compatible with a company's economic interest. Stakeholder theory (Donaldson \& Preston, 1995; Freeman, 1994) supporting stakeholders interest, explain that companies must satisfy a range of interested parties such as NGOs, customers, suppliers and residents' associations but also shareholders. The main point here is that it can be rational to take measures that reduce short-term profits if they satisfied the interests of stakeholders which are deemed to be strategic. This approach broadens the range objectives that company should seek to attain. While Friedman's criticism (1970) criticism that the role of executives is only to make profits, since they work for 
shareholders and for no one else. The consideration here is that a company's survival depends on more than profit maximization alone. Lastly, a fourth approach seeks to neutralize Friedman's argument by explaining that, all in all, it is in a company's economic interest to engage in socially responsible practices. This approach has been described as instrumental by Garriga and Melé (2004) since it demonstrates the fundamental compatibility between economic and 'social' performance. Several researches and reviews have proposed the importance of government intervention in promoting corporate social responsibility (CSR). Laura A., Josep M., Antonio T., Atle M., and Francesco P. (2008) basing on the analysis of an explanatory framework related to the development of a relational analytical framework, they tried to analyze the vision, values, strategies and roles adopted by governments, and the integration of new partnerships that governments establish in the CSR area with the private sector and social organizations. By comparing CSR initiatives and public policies in three European countries: Italy, Norway and the United Kingdom, and focuses on governmental drivers and responses. They found that governments are incorporating a common statement and discourse on CSR, working in partnership with the private and social sectors. For governments, CSR implies the need to manage a complex set of relationships in order to develop a win-win situation between business and social organizations. Although the contemporary CSR agenda is maturing, the term "CSR" has not yet taken hold within many public sector agencies, either in industrial or developing countries. Few government initiatives have been undertaken explicitly as "pro-CSR initiatives" but nonetheless many have contributed effectively to the promotion of greater social responsibility. For example, the primary incentive of public sector activities that promote exports of sustainability produced goods and services might well be to earn foreign exchange, but they still have a positive impact by encouraging responsible production. Public sector agencies that do not use the expression "corporate social responsibility" are not necessarily doing any less than those that do. The challenge is for public sector bodies to identify priorities and incentives that are meaningful in the local and national context and to build on existing initiatives and capacities. There is a significant opportunity for public sector bodies in developing countries to harness current enthusiasm for "CSR" alongside key public policy goals and priorities to encourage delivery of results in both respects. Corporate social responsibility application in various developing countries has a single divergence based on political and cultural issues. Laura A., Joseph M., Antonio T., Atle M., and Francesco P. (2008) focusing on the differences between the three governments when applying CSR public policies found that These divergences are based on the previous cultural and political framework, such as the welfare state typology, the organizational structures and the business and social and cultural background in each country. Corporate Governance in Togo context is often interpreted as the sum total of value based decisions and actions taken by people at all levels in the organization. It is an instrument to maximize shareholder value. Togo government believed that Good corporate governance is vital to integrity and efficiency of financial markets; Poor corporate governance on the other hand weakens a company's potential and perhaps can pave the way for financial difficulties and even frauds. Companies should have well governed, and they will usually outperform other companies and will be able to attract investors whose support can help to finance further growth. Togo governments have joined other stakeholders in assuming a relevant role as drivers of CSR (Moon 2004) and adopting public sector roles in strengthening CSR (Fox et al. 2002). At the start of the century, these governmental initiatives converged with the actions of different international organizations such as the UN Global Compact and the European Commission 1, both of each began to promote and endorse CSR, recognizing that the role of public administration and public policy initiatives were key in encouraging a greater sense of CSR. Looking at the political agenda, the increasing profile of CSR as a concept in government action is linked to other challenges brought about by globalization and economic change in the late 20th century (Aaronson \& Reeves 2002b, Fox et al. 2002), such as the debate on corporate citizenship, the changing role of business in society (Detomasi 2007) and the interrelationship between trade, investment and sustainable development. Suggest by several theories the strategic roles to be played by government's focus on the collaborative aspect between government and the different stakeholders involved in business. In this sense, the literature had mentioned that one of the emerging themes regarding the role of government in the development of CSR is emphasized on its role as mediator, facilitator and partner. As a result, one of the aspects most analyzed by the literature is the relationship between CSR and the development of partnership policies to promote CSR. Pioneers in the analysis of the CSR and partnership link are Nelson \& Zadek (2000), within the framework of work carried out by The Copenhagen Centre, one of the seminal institutions for research in this area. Gribben et al. (2001) have also linked government CSR roles to their strategies in the creation of new models of social partnership. The authors compare the most innovative countries in these social partnerships, concluding that central governments could adopt partnerships to solve specific social problems in conjunction with companies, social organizations and local governments. In the way, Some hypotheses are analyzed in relation to CSR partnerships: the whole process from collective bargaining to social partnerships, and the new roles of social partners in Europe (Kjaergaard \& Westphalen 2001) and CSR roles in public private partnerships as models of governance. Governance of CSR public or private partnerships bring us to the policy network concept, whereby from a more consistent and longterm perspective, public and private (profit and non-profit) actors play different roles in the same policy fields. One of the aspects that stand out in these comparative and contextual analyses of government actions is the relationship between 
development of CSR public policies and the importance of political, cultural and geographical aspects. Aaronson \& Reeves (2002a) compare Europe and the United States in terms of their acceptance of the government's role in promoting CSR. Their research demonstrates that there is greater acceptance among European companies and less in the United States, the key in Europe being their governments' positive cooperation with companies. They consider that the difference resides in the respective business cultures. European firms are more comfortable both working with government to improve social conditions and in a regulated environment. In this respect, various studies had recommended North American Asian-African developing countries governments to assume leadership and demonstrate commitment, communication and action (CBSR 2001), and strong partnership to tackle the new challenges in governance arising from globalization (The Frank Hawkins Kenan Institute of Private Enterprise 2003).

\section{Relationship Between Governance Interference in CSR and CG}

The key element that can be underlined from our analysis is that in the last decade, Togo governments have begun to work in partnership with other agents private and public such as businesses as social organizations to solve societal governance challenges. This strategy adopted by government is based on a relational strategy that could be applied in the analysis of CSR and corporate governance. And finally, our analysis on government interference in both CSR and CG reveals that government plays the same role at the same level. From key elements obtained from the review of the state of the art is that the analysis of government interference in CSR and CG has led us to identify the new vision, strategy, objectives and priorities adopted by governments in relation with business. From these conclusions and previous work by Albareda et al. (2004) and Midttun (2004) we have designed an anarchically framework by the figure 1 showed below that lets us understand the new strategies adopted by governments in relation with privates and public institutions to promote CSR and CG.

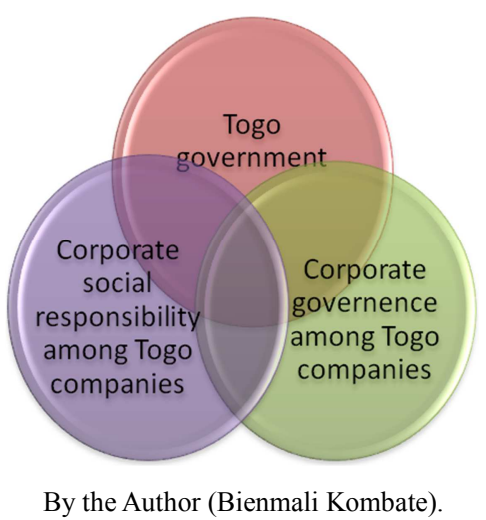

Figure 1. Relational Model Analyzing the Key Role of Togo Government in Ethical Behavior in Corporate Social Responsibility (CSR) and Corporate Governance (CG).

\section{Discussion and Conclusion}

With previous studies such as Albareda et al. (2004), Laura A., Josep M., Antonio T., Atle M., and Francesco P. (2008), Lozano et al. (2005) and Midttun (2005) as reference, we developed an analytical framework to map and analyze the existing CSR and CG programs developed by governments. We went on to give a classical analysis by classifying the government interference in both CSR and CG. Our main intent in this paper was to know the keys role of Togo government in business ethical behavior among companies, to understand if the relationship between corporate governance mechanisms and corporate social responsibility dimensions was contingent on the levels of slack and performance attainment discrepancy. In doing so, we try to seek by classical analysis of the ambiguity basing on previous findings by considering positive dimensions of government interference in CSR and CG. The comprehensive bundle of the governance mechanisms, and two important factors namely, attainment discrepancy and slack, based in the behavioral theory of the firm. Our basic analysis showed that effective governance has a symmetric effect on CSR and CG. Second, our analysis also permit us to suggest that greater trust and positive believing by companies in government can lead to higher promoting of CSR and CG. Finally, we conclude that the associations between effective CSR and CG practice in companies are the results of good ethical behavior. Our findings highlight the importance of both CSR and CG in organizational contexts in ethical behavior need government intervention. We suggest futures to studies to seek the impact of governance intervention on managerial decision-making regarding CSR and CG. Overall, our findings provide strong affirmation of the need of government in CSR and CG.

\section{Related Websites}

Inter Relationship between Business Ethics and Corporate Governance among Indian Companies

https://www.academia.edu/1015118/

The changing role of governments in corporate social responsibility: drivers and responses

http://www.eurada.org/files/Social\%20affairs/CSR\%20Bus iness\%20Ethics.pdf

Public Policy for Corporate Social Responsibility

http://info.worldbank.org/etools/docs/library/57434/public policy_econference.pdf

Corporate Governance and Corporate Social Responsibility (CSR): The Moderating Roles of Attainment Discrepancy and Organizational Slack

http://www.cairn.info/revue-management-2015-3-page234.htm

\section{References}

[1] Aaronson, S. \& Reeves, J. (2002a). The European Response to Public Demands for Global Corporate Social Responsibility. Washington, D. C.: National Policy Association. 
[2] Aaronson, S. \& Reeves, J. (2002b). Corporate Social Responsibility in the Global Village: The Role of Public Policy. Washington, D.C.: National Policy Association.

[3] Albareda, L., Ysa, T., Lozano, J. M. (2004). "The Role of Public Policies in Promoting CSR: A Comparison among the EU-15." Paper presented at the Interdisciplinary CSR Research Conference, Nottingham.

[4] Albareda, L., Ysa, T., Lozano, J. M. (2005). The Role of Governments in Fostering CSR. In A. Kakabadse \& M. Morsing (Eds), Corporate Social Responsibility. Reconciling Aspiration with Application. Houndmills: Palgrave.

[5] Ahmad Z (2014); what are business ethics? Research gate. Link:

https://www.researchgate.net/post/What_are_business_ethics.

[6] Detomasi. D. (2007). The Multinational Corporation and Global Governance: Modelling Global Public Policy Networks. Journal of Business Ethics (2007) 71:321-334.

[7] Freeman RE (1994) The politics of stakeholder theory: some future directions. Business ethics quarterly 4:409-421.

[8] Friedman M (1970) The social responsibility of business is to increase profits. N Y Times Mag 32-33, 122-126, Sept 2013Fox, T., Ward, H. and Howard, B. 2002. Public Sector Roles in Strengthening Corporate Social Responsibility: A Baseline Study. Washington, DC: World Bank.

[9] Garriga E, Mele D (2004) Corporate social responsibility theories: mapping and territory. J Bus Ethics 53:51-74.

[10] Gribben, C., Pinnington, K. Wilson, A. (2001). Governments as Partners: The Role of the Central Government in Developing New Social Partnerships. Copenhagen: Copenhagen Center.

[11] Jorge (2014); what are business ethics? Research gate. Link: https://www.researchgate.net/post/What_are business_ethics.

[12] Kjaergaard, C. \& Westphalen, S. (2001). From Collective Bargaining to Social Partnerships: New Roles of the Social Partners in Europe. Copenhagen: The Copenhagen Centre.

[13] Laura A, Josep M. Lozano, Antonio Tencati, Atle M. and Francesco P.(2008). The changing role of governments in corporate social responsibility: drivers and responses. Business Ethics: A European Review Volume 17 Number 4 October 2008.

[14] Lee, M. (2008). A review of the theories of corporate social responsibility: its evolutionary path and the road ahead. International Journal of Management Reviews, 10, pp. 53-73.

[15] Midttun, A. 2004. 'Realigning business, government and civil society: the $\mathrm{C}(\mathrm{S}) \mathrm{R}$ model compared to the (neo)liberal and welfare state models.' Paper presented at the 3rd Colloquium of the European Academy of Business in Society, Ghent.

[16] Moon, J. 2004. 'Government as a driver of corporate social responsibility: the UK in comparative perspective.' ICCSR Research Paper Series, 20-2004. ICCSR, University of Nottingham, pp. 1-7.

[17] Nelson, J. and Zadek, S. 2000. Partnership Alchemy -New Social Partnerships in Europe. Copenhagen: The Copenhagen Centre.

[18] Nelson, J. \& Zadek, S. (2000). Partnership Alchemy - New Social Partnerships in Europe. Copenhagen: The Copenhagen Centre.

[19] The Frank Hawkins Kenan Institute of Private Enterprise. 2003. Promoting Global Corporate Social Responsibility. The Kenan Institute Study Group Consensus. Policy Recommendations. Washington, DC: The Frank Hawkins Kenan Institute of Private Enterprise.

[20] Peter D. (1992), Managing for the Future (New York: Harper Collins).

[21] Robert Allen Peterson, O. C. Ferrell (2005). Business ethics: new challenges for business schools and corporate leaders. M. E. Sharpe.

[22] Vogel DJ (2005) Is there a market for virtue? The business case for corporate social responsibility. Cal manage rev 47(4):19-4.

[23] Zadek, S. (2001a). The Civil Corporation: the New Economy of Corporate Citizenship. London, Stirling, VA: Earthscan.

[24] Zadek, S. (2001b). Third Generation Corporate Citizenship. London: The Foreign Policy Center and Accountability. 